\title{
Coating Microspheres with Zirconium Carbide-Carbon Composite by the Methylene Dichloride Process
}

\author{
By \\ Katsuichi IKAWA and Kazumi IWAMOTO \\ (Japan Atomic Energy Research Institute)
}

\section{Introduction}

Pyrolytic carbon is used for coating particle fuels for high temperature nuclear reactors ${ }^{1)}$. Pyrolytic zirconium carbide is also proposed to be used for coating such nuclear fuels ${ }^{2)}{ }^{2)}$. Codeposited composite of these two materials, i.e., zirconium carbide-carbon composite, or zirconium carballoy as we call it for shortening, is expected to have a higher mechanical strength ${ }^{5}$ and better thermal shock resistance ${ }^{6}$ than pure pyrolytic carbon and to be better than stoichiometric zirconium carbide from view points of neutron economy and helium damage $e^{7}$. Neutron irradiation stability of the carballoy has not been reported, but those of titanium-doped pyrolytic carbon ${ }^{8 ;}$ and silicon-containing pyrolytic $\operatorname{carbon}^{9), 10)}$ are considerably encouraging.

The necessary first step in the development of particle nuclear fuels coated with the carballoy is to select a process for coating levitated microspheres. Since application of the conventional process for zirconium carbide, in which zirconium tetrachloride was directly fed to the coating apparatus, was found to have a technical difficulty ${ }^{11}$, three new processes, methyl iodide process ${ }^{12)}$, methylene dichloride process ${ }^{13)}$, and chlorine process have been investigated by using stationary substrates. However, application of the new processes to coat levitated microspheres have not been tested yet, except for a simple preliminary test $^{14)}$ of the methyl iodide process. The purpose of the present investigation is to obtain qualitative information on a possibility of application of the methylene dichloride process to coat microspheres using spouted bed technique ${ }^{15)}$.

\section{Experimental}

Experimental apparatus, schematically shown in Fig. 1, consisted of two vertically mounted resistance furnaces, a deposition furnace and a reaction furnace, a methylene dichloride vaporizer and gas supply lines. A mullite furnace tube of $20 \mathrm{~mm}$ inside diameter was inserted through the

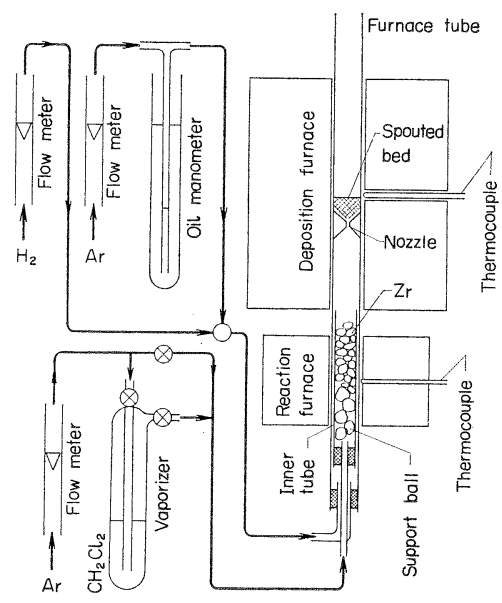

Fig. 1. Experimental apparatus for coating microspheres with zirconium carbide-carbon composite.

two furnaces. An alumina nozzle of $90^{\circ}$ cone angle and of $3.6 \mathrm{~mm}$ hole diameter was attached inside the furnace tube and the center of the nozzle was located 2 or $7 \mathrm{~cm}$ (see Fig. 3 5) below the center of the deposition furnace. A quartz tube of $18 \mathrm{~mm}$ outside diameter (length shown in Fig. $3 \sim 5$ ), in which about 30 granules of reactor grade zirconium sponge weighing about $30 \mathrm{~g}$ were packed, was inserted into the furnace tube to such a position that the sponge zone covered the temperature region of $400^{\circ} \sim 600^{\circ} \mathrm{C}$ of the reaction furnace.

About $10 \mathrm{~g}$ of highly sintered alumina microspheres measuring $0.5 \sim 0.7 \mathrm{~mm}$ diameter was charged over the nozzle. The microspheres were continuously levitated by a gas mixture spouted upward through the nozzle. Reagent grade methylene dichloride was vaporized by bubbling with carrier argon and carried into the sponge zone, where methylene dichloride vapor reacted with the sponge to generate zirconium tetrachloride and methylene radical. The reaction products were decomposed in the spouted bed, and zirconium and carbon were deposited simultaneously. A mixture of argon and hydrogen was supplied 
through the annulus between the furnace tube and the inner tube to maintain the micropheres at a given spouted condition. The purities of argon and hydrogen used were $99.999 \%$ and 99.96 $\%$, respectively. The temperature of vaporization of methylene dichloride was $0^{\circ} \mathrm{C}$ and the flow rate of the bubbling argon was $400 \mathrm{cc} / \mathrm{min}$ throughout the present series of experiments. Deposition time was intended to be $60 \mathrm{~min}$ throughout, but sometimes deposition was terminated before $60 \mathrm{~min}$ due to nozzle blockage as indicated in Figs. 3 and 4 . Methylene dichloride supply in case of $60 \mathrm{~min}$ vaporization amounted to $18 \mathrm{~g}$.

Determination of zirconium and carbon in the coating layer was carried out in the same way as described in the previous paper ${ }^{12)}$. However, the accuracy was found to be much worse than in the previous case, because the unknown weight loss of the substrates which can be attributed to the reaction of the substrate with halogen was much more in the present chloride process than in the previous iodide process. In an extreme case, zirconium may be about $10 \mathrm{mg} / \mathrm{g}$ charge more than those determined.

Fig. 2 shows the temperature distribution inside the furnace tube in the case that the temperature controller of the deposition furnace was set at $1400^{\circ} \mathrm{C}$. Similar shapes of distribution curves were obtained also for other set temperatures. Since the nozzle was located below the center of the furnace by the aforementioned distances, deposition proceeded actually at temperatures lower than the furnace temperatures stated in the captions of Figs. 3 5. The reason why the nozzle was not located at the furnace center is based on the consideration that the ratio of deposition on the microspheres to that on the furnace tube wall will be increased by locating the nozzle in a steeper temperature gradient.

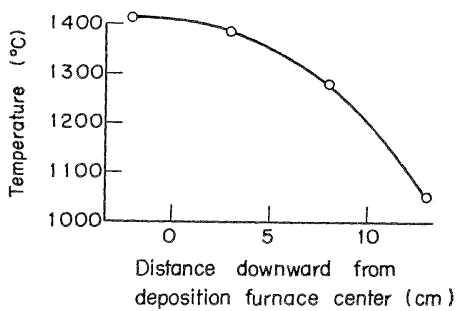

Fig. 2. Temperature distribution inside the furnace tube.

X-ray diffraction analysis was made directly on coated particles arranged as a single layer on a specimen holder, because removal of coating layer from the substrate particles was difficult.

\section{Results and discussion}

Experimental results are summarized in Fig. 3

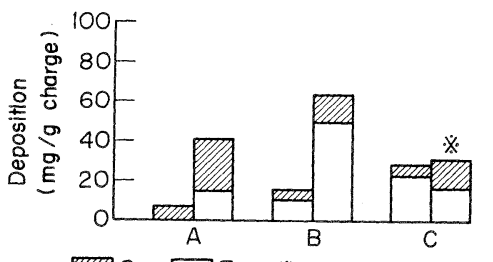

T,

hydorogen conc. A $13 \%$, B $26 \%$, C $39 \%$

total gas flow rate $2300 \mathrm{cc} / \mathrm{min}$

inner tube length $29 \mathrm{~cm}$

nozzle $7 \mathrm{~cm}$ below furnace center

Fig. 3. Comparison of deposition between two furnace temperatures, $1300^{\circ} \mathrm{C}$ (left) and $1400^{\circ} \mathrm{C}$ (right).

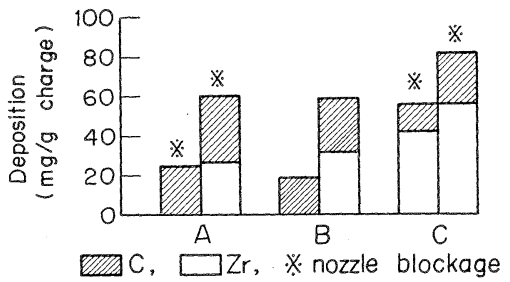

hydrogen conc, A $31 \%, \mathrm{~B} 46 \%$, C $53 \%$ total gas flow rate A, B $1300, \mathrm{C} 1700 \mathrm{cc} / \mathrm{min}$ inner tube length $29 \mathrm{~cm}$ nozzle A, B $2 \mathrm{~cm}, \mathrm{C} 7 \mathrm{~cm}$ below furnace center

Fig. 4. Comparison of deposition between two furnace temperatures, $1400^{\circ} \mathrm{C}$ (left) and $1500^{\circ} \mathrm{C}$ (right).

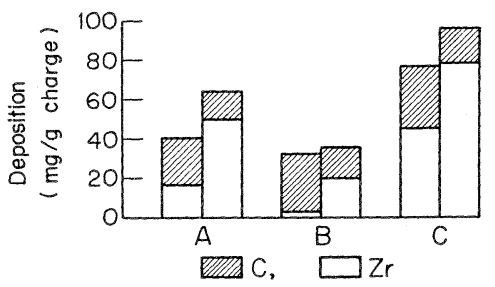

hydrogen conc. A $26 \%$, B $35 \%$, C $53 \%$ total gas flow rate A $2300, \mathrm{~B}, \mathrm{C} 1700 \mathrm{cc} / \mathrm{min}$ nozzle $7 \mathrm{~cm}$ below furnace center $\left(1400^{\circ} \mathrm{C}\right)$

Fig. 5. Comparison of deposition between two inner tube length, $34 \mathrm{~cm}$ (left) and $29 \mathrm{~cm}$ (right).

5. These bar graphs are so arranged that two bars make a couple and that the two counterparts (left and right) of each couple represent the identical conditions except for the comparison condition stated in each figure caption. Take B couple in Fig. 4, for example. The left counterpart represents the amount of deposition obtained at $1400^{\circ} \mathrm{C}$ and the right one at $1500^{\circ} \mathrm{C}$, experimental conditions other than the deposition furnace temperature being identical. The amounts of deposition in these graphs are those measured after 60 min deposition. In the cases that the deposition was terminated before $60 \mathrm{~min}$ due to nozzle blockage as indicated in the graphs, the amounts of deposition in $60 \mathrm{~min}$ were calculated for the graphs assuming time-deposition proportionality. Although zirconium consumption could not be measured because of premature deposition of 
carbon on the sponge, chlorine efficiency, which was defined by the number of chlorine atoms incorporated to zirconium deposition on microspheres for every 100 chlorine atoms supplied as methylene dichloride, could be conveniently used as a measure of zirconium deposition yield. Similarly defined carbon efficiency served as a measure of carbon yield. $100 \%$ chlorine and carbon efficiencies corresponded to the depositions of $970 \mathrm{mg}$ $\mathrm{Zr} / \mathrm{g}$ charge and $260 \mathrm{mgC} / \mathrm{g}$ charge, respectively. Fig. 3 5 show that chlorine efficiency lies below $10 \%$ under any condition investigated and carbon efficiency appears to be higher than $10 \%$ in some cases.

Fig. 3 and 4 show that the deposition yield is higher at higher temperature. This is also valid for the case in which the nozzle is located near the center of the deposition furnace (see Fig. 4, $\mathrm{A}$ and $\mathrm{B}$ ). This observation agrees qualitatively with thermodynamic prediction that zirconium tetrachloride decomposes to a larger extent at higher temperature. Coating thickness measured by an optical microscope after $60 \mathrm{~min}$ deposition is around 10 microns even under appropriate conditions at $1400^{\circ} \mathrm{C}$, accordingly deposition below $1400^{\circ} \mathrm{C}$ is not practical. Fig. 5 shows that the use of the longer inner tube results in more carbon and less zirconium deposition. In the depositionexperiment using stationary substrates ${ }^{13)}$, decrease in hydrogen supply resulted in more carbon and less zirconium deposition. In the case of Fig. 5, hydrogen came into contact with the reaction products at about $1250^{\circ} \mathrm{C}$ when the longer inner tube was used, whereas the contact occurred at about 1000 ${ }^{\circ} \mathrm{C}$ when the shorter tube was used. With increasing the temperature, the probability of mutual collision of reaction products increases, resulting the collision products to grow to larger and less active agglomerates and hydrogen to become less effective. This is a tentative explanation for the tube length effect. In addition, comparisons between $\mathrm{A}, \mathrm{B}$ and $\mathrm{C}$ in Fig. 3, between $\mathrm{A}$ and $B$ in Fig. 4 and between $B$ and $C$ in Fig. 5 (within each combination for comparison, deposition conditions other than hydrogen concentration are identical) show that, with the exception of the right one of $\mathrm{C}$ couple in Fig. 3, increase in hydrogen concentration tends to result in less carbon and more zirconium deposition. This tendency agrees with that observed in the stationary substrate experiment ${ }^{13)}$. The effect of the total gas flow rate is not clear in Fig. 3 5. It will depend on the deposition furnace temperature and the nozzle location.

$\mathrm{X}$-ray diffraction pattern of coated microspheres from a typical batch, shown in Fig. 6, reveals the existence of only zirconium carbide phase in the

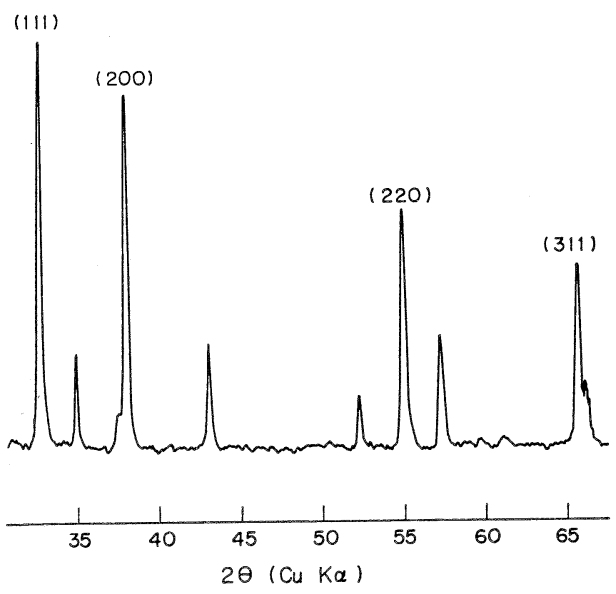

Fig. 6. X-ray diffraction of microspheres coated with zirconium carbide-carbon composite.

(sample : Fig. 5. C, left, 12 micron thick)

coating layer, except small diffraction peaks from the substrate. The ratio of the intensities of the four strongest peaks indicated with Miller indexes is about the same as that of ASTM powder pattern ${ }^{16)}$. The resemblance of the peak intensity ratio to that of the powder pattern is an evidence for the fact that the zirconium carbide phase does not exist in turbostratic structure, which implies that the codeposition of the large excess of free carbon did not disturb the lattice formation of zirconium carbide. Coated microspheres from other batches showed similar diffraction patterns, although the ratio of peak intensities of zirconium carbide to those of the substrate differed depending on coating thickness. Carbon phase was not detected by X-ray diffraction analysis even in the case of considerably carbon rich coating, probably because free carbon was not well crystallized.

One of the most important practical problems is to prevent the nozzle from blocking. Reduction of the supply rate of methylene dichloride will be a simple solution, considering that increase in the supply rate by elevating the vaporization temperature to $20^{\circ} \mathrm{C}$ caused nozzle blockage in only $16 \mathrm{~min}$ operation. This solution, however, is not recommendable because deposition rate is decreased. Lowering the nozzle while holding the spouted bed at high temperature was expected to be a possible solution. A two-stage nozzle shown in Fig. 7 was designed and machined from gra-

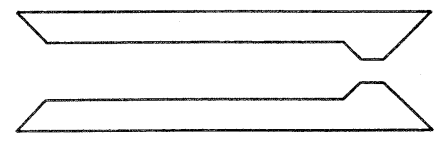

$\perp$ upward

Fig. 7. Lateral cross-section of two-stage nozzle. 


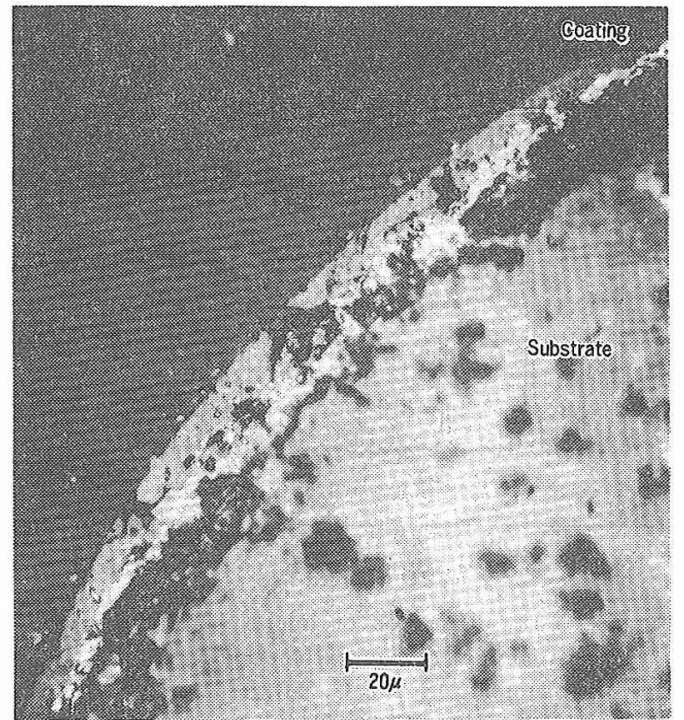

Fig. 8. Microphotograph of zirconium carbide-carbon composite coating on alumina particle substrate. (sample : Fig. 4. B, right)

phite, but the operation with this nozzle did not offer any improvement. Separating the nozzle from the spouted bed to a larger extent will be necessary. Nozzle blocking mechanism is not well understood. Long whiskers of the deposition product as observed in the stationary substrate experiment ${ }^{13)}$ may play an important role.

Coatings obtained under some conditions were not adherent. In the worst case coating layer was completely removed in the course of polishing for microscope observation. Coatings obtained under conditions of low deposition rate seem to be adherent. Fig. 8 shows an example of a rather brittle coating layer. Any detailed discussion on this subject requires further investigation.

\section{Conclusion}

The process for vapor deposition of zirconium carballoy from reaction products between zirconium sponge and methylene dichloride vapor is applicable to coat levitated microspheres. Carbon to zirconium ratio in the coating layer can be controlled by changing either hydrogen concentration or the length of the inner tube for the reaction zone. Deposition below $1400^{\circ} \mathrm{C}$ is not practical.

\section{References}

1) M.T. Simnad, "Fuel Element Experience in Nuclear Power Reactor" Gordon and Breach Sci. Pub., New York, London, Paris (1971).

2) Japan Pat. 47-19, 320 (1972).

3) Brit. Pat. 998, 274 (1964).

4) Brit. Pat. 1, 206, 927 (1970).

5) C.F. Powell, J.H. Oxley and J.M. Blocher, Jr., "Vapor Deposition", John Wiley, New York, London, Sydney (1967) p. 663.

6) Brit. Pat. 967, 565 (1964).

7) Gulf General Atomic Report GA-8662, U.S. Atomic Energy Commission (1968) p. 113.

8) R.J. Price and J.C. Bokros, Carbon 9 [2] 205 (1971).

9) J.C. Bokros, D.W. Stevens and R.J. Akins, ibid. g [4] 439 (1971).

10) J.L. Kaae, D.W. Stevens and J.C. Bokros, ibid. 10 [3] 285 (1972).

11) K. Ikawa, F. Kobayashi and K. Iwamoto, 1970 Fall Meeting on Nuclear Fuels and Materials, Japan.

12) K. Ikawa, J. Less-Common Metals 27 [3] 325 (1972).

13) K. Ikawa, ibid. 23 [3] 233 (1972).

14) K. Ikawa and K. Iwamoto, J. Nucl. Mat., 45 [1] 67 (1972).

15) M. Leva, "Fluidization" McGraw-Hill, New York (1959) p. 169.

16) G.G. Johnson, Jr. and V. Vand, "KWIC Guide to the Powder Diffraction File" American Society for Testing and Materials (1968) Card No. 11-110.

[Received October 25, 1972]

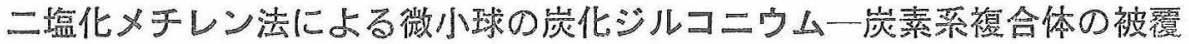

\section{井川勝市・岩本多賔 （日本原子力研究所）}

流動層で贁小球に炭化ジルコニウム一炭素系複合体の 被覆を施こす方法として、ジルコニウムスポンジと二塩 化メチレン蒸気との反灾生成物からの蒸着が利周できる ことを実証した．蒸着物層の炭素対ジルコニウム比は，
供給ガス中の水素濃度变変えることによっても，また， 反応領域の管長を変えることによっても調節できる。 $1400^{\circ} \mathrm{C}$ 以下での蒸着は実用的でない.

$(10 / 25 / 1972$ 受付 $)$ 